\title{
Longitudinal change in professional divers' lung function: literature review
}

\author{
Richard Pougnet ${ }^{1,2}$, Laurence Pougnet ${ }^{3,4}$, David Lucas ${ }^{1,5}$, Marie Uguen², \\ Anne Henckes ${ }^{6}$, Jean-Dominique Dewitte ${ }^{1,2}$, Brice Loddé ${ }^{1,2}$ \\ ${ }^{1}$ Maritime Medicine French Society (SFMM), Brest, France \\ 2Environmental, Maritime and Professional Pathologies Centre, University Hospital of Morvan, Brest, France \\ ${ }^{3}$ Federation of Laboratories, University and Military Hospital, Brest, France \\ ${ }^{4}$ Val de Grâce Medicine School, Paris, France \\ ${ }^{5}$ Service de santé au Travail en Iroise, Brest, France \\ ${ }^{6}$ Hyperbaric Medicine Centre, University Hospital of Morvan, Brest, France
}

\begin{abstract}
Background: The aim of this study was to assess changes in lung function of professional divers. Materials and Methods: This is a review of the literature. Only studies about professional divers were included. All published studies between 01.01.1984 and 07.01.2014 were systematically searched. The search was performed in Medline and Embase databases and in the "Medicina Maritima" journal. The results of pulmonary function tests were extracted from each study.

Results: Fifteen articles were found. Four studies showed a significant decrease in forced vital capacity (FVC). Five studies demonstrated a significant decrease in forced expiratory flows (FEF) at $75 \%$ and $50 \%$ of FVC expired $\left(F E F_{75 \%}\right.$ and $\left.F E F_{50 \%}\right)$ after 3 years of diving. Seven studies demonstrated a significant decrease in forced expiratory volume in 1 second $\left(F E V_{1}\right)$ after 3 years of diving. But only 2 studies did an age-standardisation so that only 1 study demonstrated a significant decrease in $\mathrm{FEV}_{1}$ after age-standardisation. Three articles showed a decrease in transfer factor for carbon monoxide $\left(T L_{C O}\right)$ after 5 years. Dives parameters (like depth, number by year) were not always related to variations on the different lung variables.

Conclusions: This literature review showed a decrease in $\mathrm{TL}_{\mathrm{CO}}, \mathrm{FEF}_{75 \%}$ and $F E F_{25-75 \%}$. One wonders whether these variations are due to the age or to diving. The results of such a long-term study would be interesting and might help to guide fundamental research.
\end{abstract}

(Int Marit Health 2014; 65, 4: 223-229)

Key words: diving, respiratory function tests, occupational medicine

\section{INTRODUCTION}

The divers' respiratory system is subject to the constraints of hyperbaric environment [1]. Firstly, underwater exercise is responsible for the reduction in lung function because the respiratory resistance increases and because the dynamic lung volumes are reduced as the pressure increases due to enhanced gas density [2, 3]. Besides, there are micro bubbles in the lungs during and after decompression so that there are gas exchange abnormalities and inflammation [4-6]. Moreover, there is oxygen toxicity to pulmonary tissue $[7,8]$.
That is why professional divers are medically monitored during medical surveillance examinations. For example in France, an initial examination includes a pulmonary function testing (PFT), a cardiac stress test, an exposure test in a hyperbaric chamber, an electroencephalogram, chest and major joints radiographs, an ear nose and throat (ENT) examination. These are compulsory tests which are required before starting a professional diving career. To go on the activity, there is also an annual mandatory examination, including PFT, cardiac stress test, ENT examination and biological tests. 


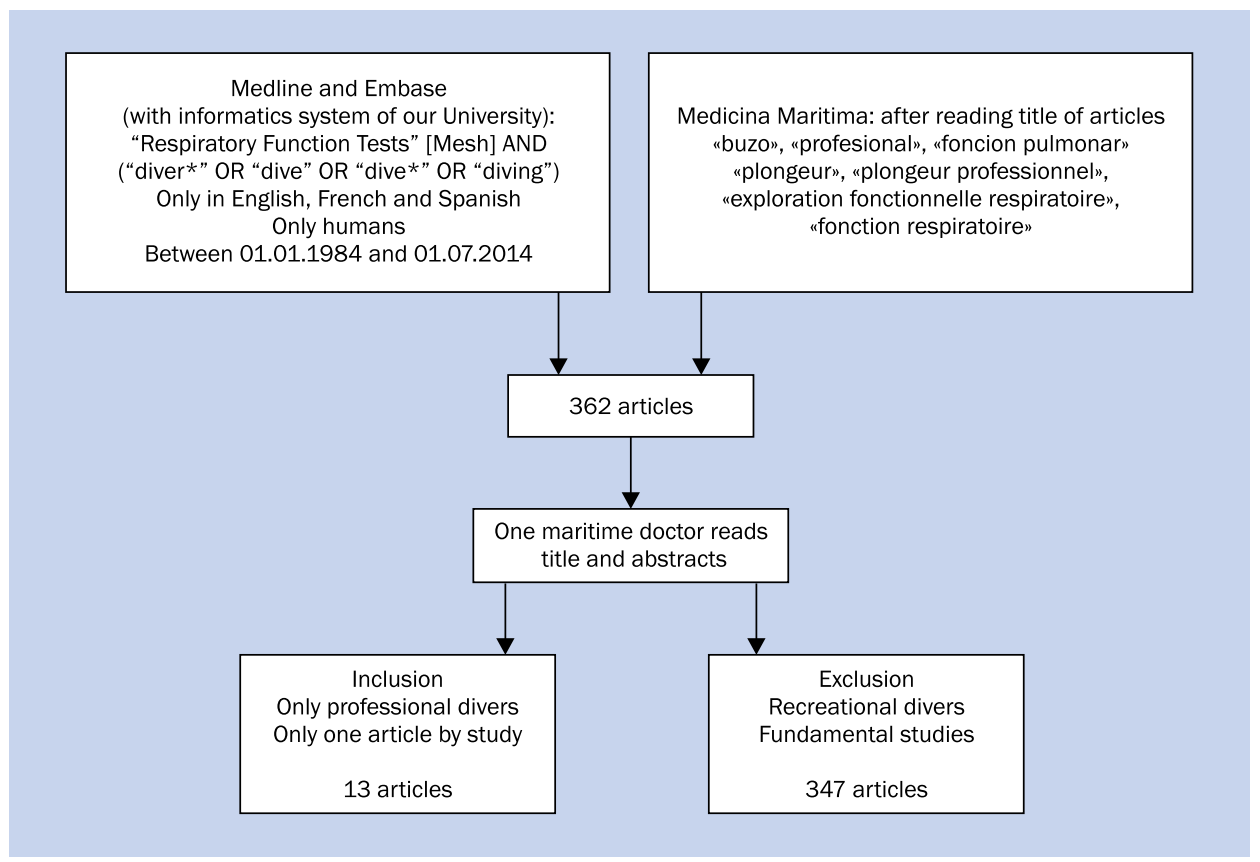

Figure 1. Flow chart

The most important aim of the PFT is to detect lung function impairments that may increase the risk of pulmonary barotraumas during the ascent, a rare but potentially serious accident among divers [9]. Recent studies have shown changes in some lung function parameters of professional divers: increase of lung volumes [10]; small airways disease [11, 12]; decrease of the transfer factor for carbon monoxide $\left(\mathrm{TL}_{\mathrm{CO}}\right)[12,13]$. The purpose of this article was to review the literature on changes in professional divers' PFT during active working in their job over several years.

\section{MATERIALS AND METHODS}

This is a review of the literature. Search has been done on the medical databases Medline ${ }^{\circledR}$, Embase ${ }^{\circledR}$, and on the site of Medicina Maritima ${ }^{\circledR}$ journal. The search was made with English, French and Spanish search terms. The key words in English were: "Respiratory Function Tests" [Mesh], "diver*", "dive", "dive*", "diving", "professional". In French, each term was used in the singular and the plural: "plongeur", "plongeur professionnel", "exploration fonctionnelle respiratoire", "fonction respiratoire". And in Spanish, each term was used in the singular and plural: "buzo", "profesional", "foncion pulmonar". "AND" and "OR" functions were used (Fig. 1).

All articles that studied professional divers' PFT (cohort and case-control studies) and published between 01.01.1984 and 07.01.2014 were included. Articles about recreational divers were excluded.

Results of PFT were analysed comparatively. The dive profiles (depth, duration, number of dives per year), the biometric data, and the socio-professional data were described. For forced expiratory volume in 1 second $\left(\mathrm{FEV}_{1}\right)$, a predicted value was performed according a decrease of $0.03 \mathrm{~L}$ per year $[14,15]$.

\section{RESULTS}

Overall, the PFT of professional divers were studied in 14 articles in the literature (Table 1) [12, 13, 16-26]. Studies of Lucas et al. [12] and Pougnet et al. [13] were both conducted in Brittany, France, in the same centre, but divers were not the same persons. Measuring devices and PFT laboratory, however, were the same and therefore the results were fully comparable.

\section{SUMMARY OF THE STUDIES}

Study of Watt [16]. In 1984, Watt conducted a longitudinal study on PFT changes in commercial divers who had attended a medical examination for offshore diving over periods of three to 9 years. Two groups of divers were made: first group with records over a 3- or 4-year interval and second group with records over an interval of 5 years or longer. In both groups, there was a significant decrease in $\mathrm{FEV}_{1}$ and forced vital capacity (FVC). There was no correlation with the diver's age, maximum operating depth, duration of diving career, or weight change (Table 2).

Study of Thorsen et al. [11]. Twenty-four Norwegian divers practiced 1 deep dive. The maximal pressure was 3.1-4.6 MPa. All of them had a medical examination 1 year after the deep dive and 22 of them were re-examined 
Table 1. Studies, type of studies, types of divers, number of divers, interval for re-examination and number of smokers

\begin{tabular}{|c|c|c|c|c|c|c|}
\hline Articles & Type of study & Type of divers & $\begin{array}{l}\text { Age - Mean } \\
\text { (SD or range) }\end{array}$ & $\begin{array}{l}\text { Number of } \\
\text { divers }\end{array}$ & $\begin{array}{l}\text { Interval for } \\
\text { re-examination }\end{array}$ & Smokers \\
\hline Watt [16] & $\begin{array}{l}\text { Longitudinal } \\
\text { prospective study }\end{array}$ & Commercial divers & $\begin{array}{l}30 \\
\text { (range 22-45) }\end{array}$ & $\begin{array}{l}224 \\
123\end{array}$ & $\begin{array}{l}3 \text { or } 4 \text { years } \\
\text { More } 5 \text { years }\end{array}$ & $\begin{array}{l}34.8 \% \\
33.3 \%\end{array}$ \\
\hline Thorsen et al. [15] & $\begin{array}{l}\text { Propective cohort } \\
\text { study }\end{array}$ & Saturation divers & 30.3 (SD 4.5) & $\begin{array}{l}24 \\
28\end{array}$ & $\begin{array}{l}1 \text { and } 4 \text { years } \\
1 \text { and } 3 \text { years }\end{array}$ & $\begin{array}{l}21 \% \\
25 \%\end{array}$ \\
\hline Bermon et al. [17] & $\begin{array}{l}\text { Longitudinal } \\
\text { prospective study }\end{array}$ & Firemen divers & 33.1 (SD 5.7) & 20 & 9 years & $0 \%$ \\
\hline $\begin{array}{l}\text { Fitzpatrick and } \\
\text { Conkin [18] }\end{array}$ & $\begin{array}{l}\text { Longitudinal } \\
\text { retrospective } \\
\text { study }\end{array}$ & $\begin{array}{l}\text { Divers who supported } \\
\text { astronaut training }\end{array}$ & $\begin{array}{l}31 \\
\text { (range 21-45) }\end{array}$ & 43 & 1 and 3 years & $33.0 \%$ \\
\hline Teztlaff et al. [20] & $\begin{array}{l}\text { Prospective } \\
\text { cohort }\end{array}$ & Military scuba divers & 28.4 (SD 6.4) & $\begin{array}{l}468 \text { divers } \\
122 \text { control subjects }\end{array}$ & 5 years & $43 \%$ \\
\hline $\begin{array}{l}\text { Skogstad et al. } \\
{[22-24]}\end{array}$ & $\begin{array}{l}\text { Prospective } \\
\text { cohort }\end{array}$ & Variable & 24.6 (SD 4.2) & $\begin{array}{l}87 \\
87 \\
37\end{array}$ & $\begin{array}{l}3 \text { years } \\
6 \text { years } \\
12 \text { years }\end{array}$ & $42.9 \%$ \\
\hline Lucas et al. [12] & $\begin{array}{l}\text { Longitudinal } \\
\text { retrospective } \\
\text { study }\end{array}$ & Variable & $40.4(-)$ & 31 & 5 years & $25.8 \%$ \\
\hline Chong et al. [25] & $\begin{array}{l}\text { Longitudinal } \\
\text { retrospective } \\
\text { study }\end{array}$ & $\begin{array}{l}\text { Divers of Republic of } \\
\text { Singapore Navy }\end{array}$ & 31.26 (SD 5.34) & 116 & 5 years & \\
\hline Sames et al. [26] & $\begin{array}{l}\text { Longitudinal } \\
\text { retrospective } \\
\text { study }\end{array}$ & Variable & $\begin{array}{l}35.6 \\
\text { (range 18-65) }\end{array}$ & 336 & 5.6 years & $9.8 \% *$ \\
\hline $\begin{array}{l}\text { Pougnet et al. } \\
\text { [13] }\end{array}$ & $\begin{array}{l}\text { Longitudinal } \\
\text { retrospective } \\
\text { study }\end{array}$ & Variable & $\begin{array}{l}42 \\
\text { (range 33-64) }\end{array}$ & 33 & $\begin{array}{l}5 \text { years } \\
10 \text { years }\end{array}$ & $25.0 \%$ \\
\hline
\end{tabular}

*7.4\% ex-smokers; SD - standard deviation

4 years after the deep dive. They were compared with 28 professional divers. For them, the maximal pressure was $0.8-1.6 \mathrm{MPa}$. For all divers $(n=52)$, the mean annual reduction in $\mathrm{FEV}_{1}$ was significantly higher than the predicted annual loss: 82 (SD 61) $\mathrm{mL}$ per year vs. $34 \mathrm{~mL}$ per year $(p<0.01)$. The most important decrease was observed at the first medical examination in the deep diver population $(n=24) 1$ year after the deep dive: loss of $210 \mathrm{~mL} \mathrm{FEV}_{1}$ (SD 84). The decrease in $\mathrm{FEV}_{1}$ in deep divers group over the 3 following years was similar to the decrease in $\mathrm{FEV}_{1}$ in professional divers group over the 3 years of follow-up.

The decrease in forced expiratory flows (FEF) at $50 \%$ of $\mathrm{FVC}$ expired $\left(\mathrm{FEF}_{50 \%}\right), \mathrm{FEF}_{75 \%}$ and $\mathrm{FEF}_{25-75 \%}$ were significantly different from predicted and reference values.

Study of Bermon et al. [17]. This was a longitudinal prospective study of 20 firemen-divers with 2 PFT separated by 9 years. They were all non-smokers and males. There were significant decreases in $\mathrm{FVC}, \mathrm{FEV}_{1}, \mathrm{FEV}_{1} / \mathrm{FVC}$ ratio, $\mathrm{FEF}_{50 \%}$, inspiratory capacity and maximal voluntary ventilation (Table 2).
Study of Fitzpatrick and Conkin [18]. This study, performed in 2003, examined changes in pulmonary function in 43 working divers breathing a $46 \%$ oxygen enriched mixture while diving at depths less than $12 \mathrm{~m}$, between initial values and 3 year evolution values [18]. When results were given in per cent of predicted value, there was a significant increase in FVC and $\mathrm{FEV}_{1}(\mathrm{p}<0.01)$. The increases in FVC and $\mathrm{FEV}_{1}$ were also significant when expressed in absolute values (Table 2). The authors thought these increase were probably due to a training effect.

Studies of Tetzlaff et al. $[19,20]$. In 2005, Tetzlaff et al. performed a retrospective study of 39 oxygen divers. The decreases in FVC and FEV 1 were not significant [19]. In 2006, Tetzlaff et al. performed a prospective controlled cohort study of 468 military scuba divers [20]. They were followed up on 5 years on average (Table 2). A control group with 122 subjects was made. There was no significant difference in the decline of $\mathrm{FEV}_{1}$ between divers and control subjects $(p=0.32)$. Over time, FEV 1 declined more rapidly in smokers than in non-smokers $(p=0.006)$ and declined more rapidly 


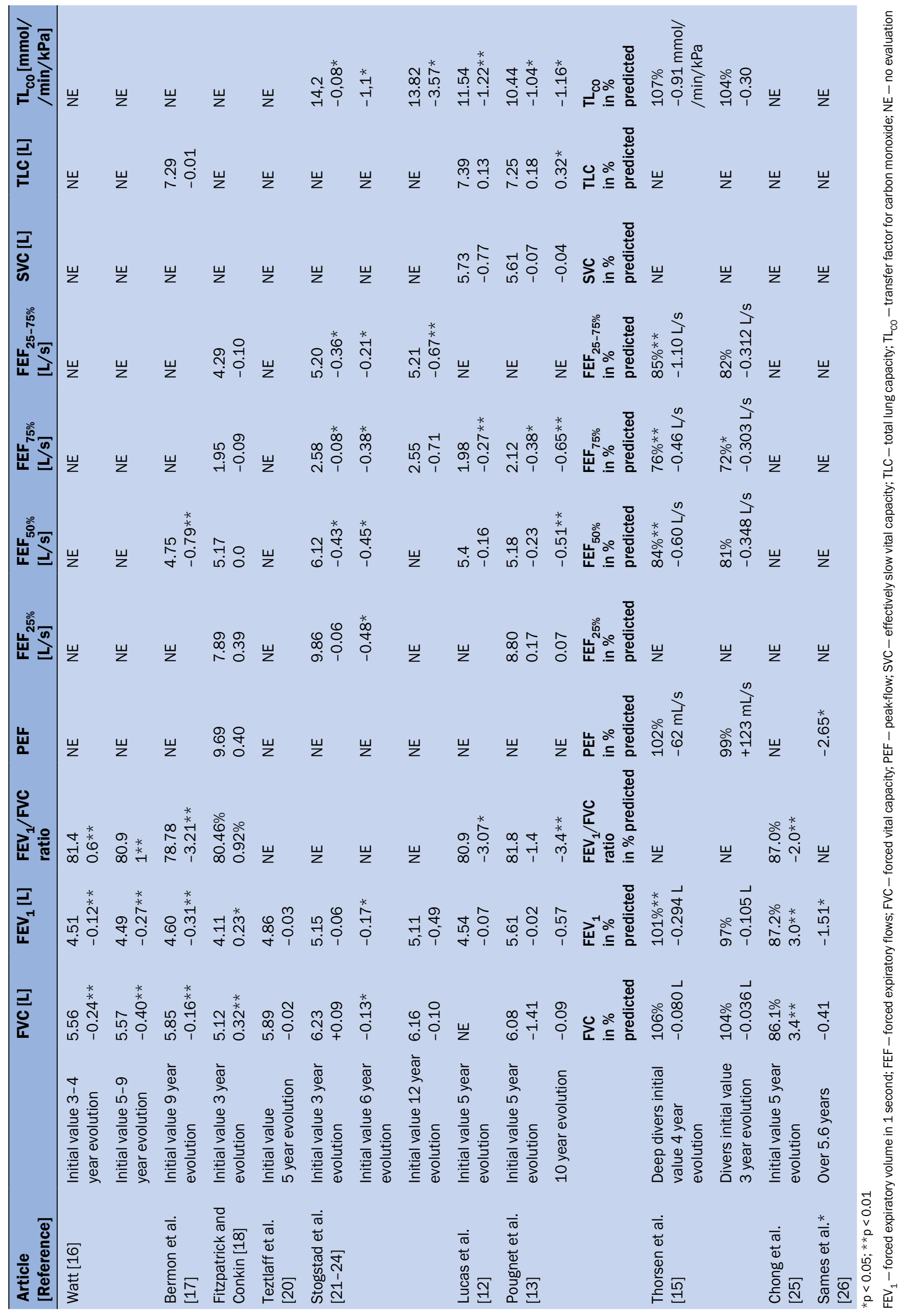


also in subjects with a baseline $\mathrm{FEV}_{1}$ above average compared to subjects with $\mathrm{FEV}_{1}$ below average $(\mathrm{p}<0.001)$.

Studies of Skogstad et al. [21-24]. In 1999, Skogstad et al. [21] performed a cross-sectional study with 1-year follow-up, The authors included 87 men early in their training as professional divers and studied lung volumes, bronchial flows and $\mathrm{TL}_{\mathrm{CO}}[22,23]$. The lung volumes were vital capacity (VC), FVC and total lung capacity (TLC). The bronchial flows were $\mathrm{FEV}_{1}$, $\mathrm{FEF}$ at $75 \%, 50 \%$ and $25 \%$ of $\mathrm{FVC}\left(\mathrm{FEF}_{75 \%}, \mathrm{FEF}_{50 \%}\right.$ and $\mathrm{FEF}_{25 \%}$, respectively) and $\mathrm{FEF}$ between $25 \%$ and $75 \%$ of FVC $\left(\mathrm{FEF}_{25-75 \%}\right)$. After 3 years, there was a significant reduction in $\mathrm{FEV}_{1}$, the $\mathrm{FEF}_{25-75 \%}$ and $\mathrm{FEF}_{25 \%}$, respectively, in mean (SD): $1.8 \%(6.5), 6.5 \%$ (11.7) and 10.4\% (16.8) (Table 2).

After 6 years of monitoring, the results showed an annual reduction of $F V C$ and $\mathrm{FEV}_{1}$, in mean (SD): 0.91\% (1.22) and $0.84 \%$ (1.28) per year and per professional diver [24]. For $\mathrm{FEF}_{25 \%}$ and $\mathrm{FEF}_{75 \%}$ reduction was related to the cumulative number of dives $(p<0.05)$ (Table 2). The authors also compared with a group of policemen who did not dive. The decrease in $\mathrm{TL}_{\mathrm{CO}}$, FVC and $\mathrm{FEV}_{1}$ was significantly higher among professional divers.

In 2008, 37 divers still belonged to the cohort [24]. They were therefore examined 4 times during 12 years of follow-up. The results showed a significant decrease in $\mathrm{TL}_{\mathrm{CO}}, \mathrm{FEF}_{25 \%}, \mathrm{FEF}_{25-75 \%}, \mathrm{FEV}_{1}$ and FVC (Table 2). The effect of the total number of dives was important for $\mathrm{FEF}_{25-75 \%}$ $(p=0.029)$.

Study of Lucas et al. [12]. In 2005, the authors retrospectively analysed 31 professional divers monitored in the medical centre of Brest (Table 2) [12]. They included divers who performed the initial medical examination and were followed for 5 years in this Brest centre. Divers may have different professions in addition to diving activity: fishermen, coast guard officers, or scientists. $\mathrm{FEF}_{75 \%}$ decreased significantly $(p=0.006)$. There was a correlation between the decrease in $\mathrm{FEF}_{75 \%}$ and depth of dives. In addition, this study showed a decrease in $\mathrm{TL}_{\mathrm{cO}}(\mathrm{p}=0.02)$, and this decrease was correlated with the number of dives.

Study of Chong et al. [25]. This was a retrospective study based on the spirometric results of divers in the navy of Singapore Republic. The divers were included during their annual recertification in 2001 and in 2006 . The results were given in per cent of predicted value. $\mathrm{FEV}_{1}$ and FVC improved significantly $(p<0.01)$. But, there was a statistically significant decrease in $\mathrm{FEV}_{1} / \mathrm{FVC}$ ratio. There was no correlation between these values and years of service or smoking history (Table 2) [25].

Study of Sames et al. [26]. In 2009, Sames et al. [26] conducted a retrospective study to analyse the PFT for 336 divers [26]. The divers who were currently registered with the regulator, the New Zealand Department of Labour, and who had completed at least 2 'full' dive medical examinations, including spirometry, with an interim period of at least 5 years, were included. The authors used 4 prediction methods: NHANES III (Third National Health and Nutrition Examination Survey), Knudson, WRS (Wellington Respiratory Survey), Gore. They analysed the correlation between variables by univariate Pearson correlation coefficients and multiple linear regression analyses. The results showed decreases in $\mathrm{FEV}_{1}(0.27 \%$ against predicted per annum, $p=0.02)$ and peak-flow $(0.47 \%$ per annum, $p=0.04)$ using the NHANES III equations (Table 2). The results revealed no significant differences in lung function parameters when the group was stratified for age and years of diving experience.

Study of Pougnet et al. [13]. In 2013, Pougnet et al. [13] also conducted a retrospective analysis of PFT for 33 professional divers followed in the medical centre of Brest. The included divers had the initial examination, the 5 year examination and the 10 year medical examination in this medical centre. Like the study of Lucas et al. [12], divers may have different professions in addition to diving activity (Table 1). Then the average differences of each parameter (between initial and 5 year medical examination and between initial and 10 year medical examination) were compared to 0 (null hypothesis: no change of the parameter) using a Student's t test. Each subject acted as his own control. Correlations were tested using a Spearman correlation coefficient.

Divers did no recreational diving before starting professional diving. Divers surveyed were not exposed to pulmonary toxic gases. The results after 10 years of professional diving showed a decrease of $\mathrm{FEF}_{75 \%}(-0.65 \mathrm{~L} / \mathrm{s})(\mathrm{p}<0.01)$ and $\mathrm{FEF}_{50 \%}(-0.51 \mathrm{~L} / \mathrm{s})(\mathrm{p}<0.01)$ (Table 2$)$. In addition, there was a decrease in $\mathrm{FEV}_{1} / \mathrm{VC}(-3.4)(p<0.01)$. Nevertheless no diver had obstructive ventilatory disorder. TLC increased $(0.32 \mathrm{~L})(\mathrm{p}=0.03) . \mathrm{TL}_{\mathrm{co}}$ decreased $(-1.16 \mathrm{mmol} / \mathrm{min} / \mathrm{kPa})$ $(p=0.02)$; this decrease was independent of smoking. Smoking was significantly correlated with changes in the slow VC $(R=0.89, p<0.01)$. Changes in $\mathrm{FEV}_{1} / \mathrm{VC}$ ratio were correlated with the average duration of dives $(R=-0.59$, $p<0.01)$ and the number of dives during the 10 years $(R=-0.42, p=0.04)$.

\section{FOCUS ON SIGNIFICANT FINDINGS}

For lung volumes, 4 studies showed a significant decrease in FVC [16-18].

For airway obstruction, 7 studies showed a significant decrease in $\mathrm{FEV}_{1}[15-18,25,26]$. Only studies of Thorsen et al. [13], Fiztpatrick and Conkin [15] and Pougnet et al. [18] showed a decrease greater than the decrease due to age (Table 3). For Skogstad et al. [21-24], it was not significant after age-standardisation. Thorsen et al. [15] made an 
Table 3. Decrease of $\mathrm{FEV}_{1}$ in the study and calculated decrease according Quanjer 1983

\begin{tabular}{lll} 
& Decrease of $\mathbf{F E V}_{\mathbf{1}}$ in the study & Predicted decrease of FEV $_{\mathbf{1}}$ \\
\hline Watt [16] & 0.12 in 3-4 years & $0.09-0.12$ \\
& 0.27 in 5-9 years & $0.15-0.27$ \\
Bermon et al. [17] & 0.31 in 9 years & 0.27 \\
Fitzpatrick and Conkin [18] & 0.23 in 3 years & 0.09 \\
Teztlaff et al. [19, 20] & 0.03 in 3 years & 0.09 \\
Stogstad and Skare [24] & 0.49 in 12 years & $0.36^{*}$ \\
Lucas et al. [12] & 0.07 in 5 years & 0.15 \\
Pougnet et al. [13] & 0.70 in 10 years & 0.30
\end{tabular}

*After adjustement with age, it was not significative; $\mathrm{FEV}_{1}$ - forced expiratory volume in 1 second

age-standardisation and the decrease was significant. So, the effect of age and tobacco need be considered (Table 3). The $\mathrm{FEF}_{25 \%}$ decreased significantly after 5 and 10 years in 2 studies $[12,13]$. In 3 studies the $\mathrm{FEF}_{50 \%}$ decreased significantly between 3 and 10 years $[13,15,17]$.

For $\mathrm{TL}_{\mathrm{CO}}$, decrease was significant in 5 studies [12, 13, 21-24].

\section{DISCUSSION}

The literature showed few data available about the changes of professional divers' PFT. Peripheral bronchial flows were reduced in the early years of professional diving, especially $\mathrm{FEF}_{75 \%}$. After 10 or 12 years, this decrease was in the larger size bronchi: $\mathrm{FEF}_{50 \%}$ and $\mathrm{FEF}_{25-75 \%}$ decrease. $\mathrm{TL}_{\mathrm{CO}}$ decreased after 3 or 5 years, depending on studies. Moreover, smoking did not seem to be the cause of this decrease.

The interest was to analyse articles from several medical databases and published in several languages. Thus, the main sources in the areas of maritime and hyperbaric medicine were considered. One might think that the limitation of this review is the lack of statistical analysis with a virtual population from different items. Indeed, a meta-analysis would have given a larger sample. However, given that the intervals between medical examination and measuring devices used were different, such an analysis would have induced bias of measurement and classification. Therefore, this methodology has not been selected.

There were several limitations to these studies in relation to professional divers' PFT. First, the samples were small to study $\mathrm{TL}_{\mathrm{CO}}$ (33 and 37 divers after 10 and 12 years). Indeed, studies were conducted on populations which may move or change their jobs, so that there were many patients lost for follow-up. Or it could also be a healthy worker effect: divers experiencing difficulties when breathing would then stop professional diving. Their careers should be more documented, in particular the reasons why they stopped diving. Second, regarding methodologies, few studies had a non-diving control group [20, 23]. Moreover, several confounding effects disturbed results. Indeed, professional divers could make several exposures. However, the Pougnet et al. [13] study took into account this possibility. In this study, divers were not exposed to other lung toxic substances. In addition, smoking was taken into account in the statistical analysis and the decrease of $\mathrm{TL}_{\mathrm{CO}}$ was not related to this addiction.

Finally, some data were not in the literature. For instance, there was no study comparing professional divers and recreational divers. Or, the detailed analysis of air mixtures used and labour exposures was incomplete. Moreover, the parameters of dives were often poor. For example, a few parameters were not studied, like temperature of water. But this parameter can affect lung function [27]. Another example, Thorsen et al. [15] showed that the changes in PFT are influenced by the depth of dives. More, a common limitation of these studies was the lack of information about cumulative diving exposure.

The analysis of professional divers' PFT changes accorded with that of recreational divers. For example, the decline in $\mathrm{FEF}_{75 \%}$ has already been described in recreational divers $[11,28,29]$. This seems to be related with the development of a small airways disease. In the literature, the effect of smoking on the PFT is shown [30]. For instance, Sekulic et al. [31] showed that smoking is correlated with large lung volume for student divers in a military centre. However, in this literature, the influence of smoking varied from one study to another. Larger samples may allow a better analysis of the possible link between diving and tobacco.

There were 4 studies which showed a significantly decrease in FVC. The analysis of this parameter is difficult, because it exists a decrease in people who are 30 years and older, whereas an increase is shown before this time $[32,33]$. 


\section{CONCLUSIONS}

Professional divers' PFT is supposed to get lower if they are exposed to hyperbaric environment for many years. In all studies, $\mathrm{TL}_{\mathrm{CO}}$ decreased from the first years of practice. It was the same for peripheral bronchial flow, especially for $\mathrm{FEF}_{75 \%}$. Some data were not studied in the literature, including the comparison of effects between recreational diving and professional diving, or the analysis of working conditions.

\section{REFERENCES}

1. Jammes $Y$, Roussos $C$. Respiration during diving. In: Roussos $C$ ed. Thorax. $2^{\text {nd }}$ Ed. Marcel Dekker Inc; New-York, Bassel, Hong Kong 1995; p. 1557-1584.

2. Moon RE, Cherry AD, Stolp BW, Camporesi EM. Pulmonary gas exchange in diving. J Appl Physiol 2009; 106: 668-677.

3. Segadal K, Gulsvik A, Nicolaysen G. Respiratory changes with deep diving. Eur Respir J 1990; 3: 101-108.

4. Butler BD, Hills BA. The lung as a filter for microbubbles. J Appl Physiol Respir Environ Exerc Physiol 1979; 47: 537-543.

5. Thorsen E, Hjelle J, Segadal K, Gulsvik A. Exercise tolerance and pulmonary gas exchange after deep saturation dives. J Appl Physiol 1990; 68: 1809-1814.

6. Hlastala MP, Robertson HT, Ross BK. Gas exchange abnormalities produced by venous gas emboli. Respir Physiol 1979; 36: 1-17.

7. Riley DJ, Kramer MJ, Kerr JS, Chae CU, Yu SY, Berg RA. Damage and repair of lung connective tissue in rats exposed to toxic levels of oxygen. Am Rev Respir Dis 1987; 135: 441-447.

8. Van Ooij PJ, Hollmann MW, van Hulst RA, Sterk PJ. Assessment of pulmonary oxygen toxicity: relevance to professional diving; a review. Respir Physiol Neurobiol 2013; 189: 117-128

9. Russi EW. Diving and the risk of barotrauma. Thorax 1998; 53 (suppl. 2): S20-S24.

10. Diniz CM, Farias TL, Pereira MC et al. Chronic adaptations of lung function in breath-hold diving fishermen. Int J Occup Med Environ Health 2014; 27: 216-223.

11. Thorsen $E$, Segadal $K$, Kambestad B, Gulsvik A. Divers' lung function: small airways disease? Br J Ind Med 1990; 47: 519-523.

12. Lucas D, Loddé B, Choucroun P et al. Étude sur 5 ans de l'évolution de la fonction respiratoire d'une cohorte de 31 plongeurs professionnels. Med Marit 2005; 5: 17-28.

13. Pougnet R, Henckes A, Mialon P et al. Evolution of the ventilatory function of professional divers over 10 years. Undersea Hyperb Med 2013; 40: 341-345.

14. Quanjer PH. Standardized lung function testing. Bull Eur Physiopathol Respir 1983; 19 (suppl. 5): 7-10.

15. Thorsen E, Segadal K, Kambestad BK, Gulsvik A. Pulmonary function one and four years after a deep saturation dive. Scand J Work Environ Health 1993; 19: 115-120.
16. Watt SJ. Effect of commercial diving on ventilatory function. $\mathrm{Br} J \mathrm{Ind}$ Med 1985; 42: 59-62.

17. Bermon S, Lapoussière JM, Dolisi C, Wolkiewiez J, Gastaud M. Pulmonary function of a firemen-diver population: a longitudinal study. Eur J Appl Physiol Occup Physiol 1994; 69: 456-460.

18. Fitzpatrick DT, Conkin J. Improved pulmonary function in working divers breathing nitrox at shallow depths. Aviat Space Environ Med 2003; 74: 763-767.

19. Tetzlaff K, Friege L, Theysohn J, Neubauer B, Muth CM. Lung function in military oxygen divers: a longitudinal study. Aviat Space Environ Med 2005; 76: 974-977.

20. Tetzlaff K, Theysohn J, Stahl C, Schlegel S, Koch A, Muth CM. Decline of $\mathrm{FEV}_{1}$ in scuba divers. Chest 2006; 130: 238-243.

21. Skogstad M, Haldorsen T, Kjuus H. Pulmonary and auditory function among experienced construction divers: a cross-sectional study. Aviat Space Environ Med 1999;70: 644-649

22. Skogstad M, Thorsen E, Haldorsen T. Lung function over 3 years of a professional diving career. Occup Environ Med 2000; 57 : 273-278.

23. Skogstad M, Thorsen E, Haldorsen T, Kjuus H. Lung function over six years among professional divers. Occup Environ Med 2002; 59: 629-633.

24. Skogstad M, Skare 0. Pulmonary function among professional divers over 12 years and the effect of total number of dives. Aviat Space Environ Med 2008;79: 883-887.

25. Chong SJ, Tan TW, Lim JY. Changes in lung function in Republic of Singapore Navy divers. Diving Hyperb Med 2008; 38: 68-70.

26. Sames C, Gorman DF, Mitchell SJ, Gamble G. The long-term effects of compressed gas diving on lung function in New Zealand occupational divers: a retrospective analysis. Diving Hyperb Med 2009; 39: 133-137.

27. Uhlig F, Muth CM, Tetzlaff K et al. Lung function after cold-water dives with a standard scuba regulator or full-face-mask during wintertime. Diving Hyperb Med 2014; 44: 70-73.

28. Davey IS, Cotes JE, Reed JW. Relationship of ventilatory capacity to hyperbaric exposure in divers. J Appl Physiol 1984; 56: 1655-1658.

29. Lemaître F, Tourny-Chollet C, Lemouton MC. Ventilatory function in experienced recreational scuba divers: evidence of small airways disease? Int J Sports Med 2006; 27: 875-879.

30. Fletcher C, Peto R. Histoire naturelle de l'obstruction bronchique des voies respiratoires. Bull Int Union Tuberc 1978; 53: 79-87.

31. Sekulic D, Tocilj J. Pulmonary function in military divers: smoking habits and physical fitness training influence. Mil Med 2006; 171: 1071-1075.

32. Davey IS, Cotes JE, Reed JW. Relationship of ventilatory capacity to hyperbaric exposure in divers. J Appl Physiol Respir Environ Exerc Physiol 1984; 56: 1655-1658.

33. Crosbie WA, Reed JW, Clarke MC. Functional characteristics of the large lungs found in commercial divers. J Appl Physiol Respir Environ Exerc Physiol 1979; 46: 639-645. 